\title{
Dental changes in Class II patients treated with Pendex appliance: a prospective study
}

\author{
Alterações dentárias em pacientes com Classe II tratados com aparelho Pendex: \\ estudo prospectivo
}

\section{Cambios dentales de los pacientes con Clase II tratados con dispositivo Pendex: estudió prospectivo}

\author{
Flávio Luis Goulart Ribeiro da SILVA ${ }^{1}$ \\ Helga Adachi Medeiros BARBOSA ${ }^{\mathbf{1}}$ \\ Derly Tescaro Narciso de OLIVEIRA ${ }^{2}$ \\ André Pinheiro de Magalhães BERTOZ ${ }^{3}$ \\ Kurt FALTIN JÚNIOR ${ }^{1}$ \\ Renato BIGLIAZZI ${ }^{3}$
}

\begin{abstract}
${ }^{1}$ Departamento de Ortodontia, Faculdade de Odontologia, UNIP Universidade Paulista 04026-002, São Paulo-SP, Brasil ${ }^{2}$ Departamento de Ortodontia, UNICASTELO Universidade Camilo Castelo Branco, 15600-000 Fernandópolis-SP, Brasil ${ }^{3}$ Departamento de Odontologia Infantil e Social, Faculdade de Odontologia de Araçatuba, UNESP-Univ Estadual Paulista, 16015-050, Araçatuba-SP, Brasil
\end{abstract}

\section{Resumo}

O objetivo deste estudo foi avaliar as alterações dentárias na maxila e as possíveis alterações verticais decorrentes da utilização do Pendex como método de tratamento ortodôntico para distalização dos molares superiores. Uma amostra por conveniência de 10 pacientes de ambos os sexos (9,3 28,8 anos; média: 15,3 anos), com necessidade de tratamento ortodôntico, foi selecionada para participação desse estudo na Faculdade de Odontologia da Universidade Paulista - FOUNIP. Duas radiografias em norma lateral foram obtidas de cada paciente, uma ao início do tratamento (T1) e outra após a distalização dos molares dos primeiros molares superiores (T2). Os cefalogramas foram traçados e mensurados pelo mesmo operador e os dados de T2 e T1 foram comparados entre si, para cada paciente. As seguintes medidas cefalométricas foram avaliadas: distância de PTV ao $1^{\circ}$ molar superior (A6-PTV), ao $1^{\circ}$ pré molar superior (A4-PTV) e ao incisivo central superior (A1-PTV), inclinação do $1^{\circ}$ molar superior (A6.PP), inclinação do $1^{\circ}$ pré molar superior (A4.PP) e a inclinação do incisivo central superior (A1.PP) em relação ao plano palatino (PP), ângulo interincisivo (A1.B1); altura facial inferior (AFI); eixo facial (EF); altura facial total (AFT). Os dados obtidos foram submetidos ao teste " $t$ " para amostras pareadas (5\%). Os valores médios e desvios-padrão obtidos para cada medida (T2-T1) foram: A6-PTV= - 4,9 $\pm 6,5 ; \mathrm{A} 4-\mathrm{PTV}=1,2 \pm 4,1 ; \mathrm{A} 1$ $\mathrm{PTV}=-1,4 \pm 7,3 ; \mathrm{A} 6 . \mathrm{PP}=9,4 \pm 7,7 ; \mathrm{A} 4 . \mathrm{PP}=-3,6 \pm 6,7 ; \mathrm{A} 1 . \mathrm{PP}=9,4 \pm 7,7 ; \mathrm{A} 1 . \mathrm{B} 1=-4,9 \pm 13,7 ; \mathrm{AFI}=1,7 \pm 2,1 ; \mathrm{EF}=-1,0 \pm 2,4 ; \mathrm{AFT}=1,0 \pm 2,7 . \mathrm{Os}$ resultados mostraram significância estatística para: A6-PTV ( $p=0,041)$; A6.PP $(p=0,004)$ e AFI $(p=0,031)$ ( $p>0,05)$. Pôde-se concluir que Pendex mostrou-se eficiente na correção da Classe II e que seus efeitos foram limitados às estruturas dentoalveolares.

Descritores: Má Oclusão de Angle Classe II; Ortodontia; Cefalometria Craniana.

\begin{abstract}
The objective of this study was to evaluate the dental changes in the maxilla and the possible facial vertical alterations of patients after using a Pendex appliance for maxillary molar distalization during their orthodontic treatment. A convenience sample of ten patients of both genders $(9.3$ to 28.8 years old; mean: 15.3 years) with a need of orthodontics treatment was selected for participation in this study at Paulista University Dental School - FOUNIP. Two lateral cephalometric radiographs were obtained for each patient, one at the beginning (T1) and the other after the distalization of the maxillary first molars (T2). The cephalograms were traced and measured by a calibrated operator and the data at T2 and T1 were compared between then for each patient. The following cephalometric measurements were taken: distance from PTV to maxillary first molar (A6PTV), to maxillary first premolar (A4-PTV) and to maxillary incisor (A1-PTV); maxillary first molar tipping (A6.PTV), maxillary first premolar (A4.PTV) and maxillary incisor (A1.PTV) to palatal plane (PP); interincisal angle (A1.B1); lower facial height (LFH); facial axis (FA) and total facial height (TFH). The data were submitted to " $t$ " test for paired samples $(5 \%)$. The mean and standard deviations obtained for each measurement $(\mathrm{T} 2-\mathrm{T} 1)$ were: $\mathrm{A} 6-\mathrm{PTV}=-4.9 \pm 6.5, \mathrm{~A} 4-\mathrm{PTV}=1.2 \pm 4.1, \mathrm{~A} 1-\mathrm{PTV}=-1.4 \pm 7.3, \mathrm{~A} 6 . \mathrm{PP}=9.4 \pm 7.7, \mathrm{~A} 4 . \mathrm{PP}=-3.6 \pm 6.7, \mathrm{~A} 1 . \mathrm{PP}=9.4 \pm 7.7, \mathrm{~A} 1 . \mathrm{B} 1=-4.9 \pm 13.7$, $\mathrm{LFH}=1.7 \pm 2.1, \mathrm{FA}=-1.0 \pm 2.4$ and $\mathrm{TFH}=1.0 \pm 2.7$. Only the A6-PTV ( $\mathrm{p}=0.041)$; A6.PP $(\mathrm{p}=0.004)$ and LFH ( $\mathrm{p}=0.031)$ angular measurements presented statistic significance ("t" test). It can be concluded that Pendex is an efficient orthodontic appliance for correcting the Class II malocclusion and that its effects were limited to dentoalveolar structures.
\end{abstract}

Descriptors: Malocclusion, Angle Class II; Orthodontics; Cephalometry.

\section{Resumen}

El objetivo de este estudio fue evaluar los cambios dentales en el maxilar y las posibles alteraciones faciales verticales de pacientes después de usar el aparato Pendex distalización molar maxilar durante el tratamiento ortodóntico. La muestra de conveniencia de diez pacientes de ambos sexos (9.3 a 28,8 años; media: 15,3 años) con la necesidad de ortodoncia tratamiento fue seleccionado para participar en este estudio en la Facultad de Odontología de la Universidad Paulista-FOUNIP. Dos radiografías cefalométricas laterales fueron obtenidas para cada paciente, al inicio (T1) y el otro después de la distalización de los primeros molares maxilares (T2). Las cefalometrías fueron trazadas y medidos por el operador y la fecha calibrada en T2 y T1 se compararon entre entonces para cada paciente. Se tomaron las siguientes mediciones cefalométricas: distancia de PTV maxilar primer molar (A6-PTV) primer premolar maxilar, (A4-PTV) e incisivo maxilar (A1-PTV); la inclinación molar primer maxilar (A6. PTV), primer premolar maxilar (A4. PTV) y el incisivo maxilar (A1. PTV) al plano palatino (PP); ángulo interincisal (A1. B1); altura facial inferior (LFH); eje facial (FA) y la altura facial total (TFH). Los datos fueron sometidos a prueba de "t" para muestras apareadas (5\%). La media y la desviación estándar obtenidos para cada medición (T2-T1) fueron: A6-PTV $=4.9 \pm 6.5, \mathrm{~A} 4-\mathrm{PTV}=1,2 \pm 4.1, \mathrm{~A} 1-\mathrm{PTV}=-7.3 \pm 1.4, \mathrm{~A} 6 . \mathrm{PP}=9,4 \pm 7.7, \mathrm{~A} 4 . \mathrm{PP}=$ $3.6 \pm 6.7$, A1. PP = 9,4 \pm 7.7, A1. B1 =-4,9 13,7 $\pm 1,7 \pm 2.1, \mathrm{LFH}=, \mathrm{FA}=1.0 \pm 2.4$ y TFH = 1,0 \pm 2.7 . Sólo el A6-PTV (p = 0,041); A6. PP (p = $0.004)$ y LFH $(p=0.031)$ mediciones angulares presentaron significación estadística (prueba de "t"). Se puede concluir que Pendex es una eficiente aplicación ortodóntica es corregir la clase II de maloclusión y que sus efectos fueron limitados a las estructuras dento-alveolares.

Descriptores: Maloclusión de Angle Clase II; Ortodoncia; Cefalometría. 


\section{INTRODUCTION}

Treatment of Class II malocclusion without skeletal involvement consists of distalization of the maxillary teeth to a Class I relationship, without having, however, any vertical alteration or involvement of the mandible arch due to such molar distalization ${ }^{1-2}$. Traditionally, this procedure has been made using extraoral forces, but according to the literature ${ }^{3-5}$ this therapy has the disadvantage of being strictly dependent on patient compliance, which may compromise the final treatment results.

In search for treatments that were less dependent on patient cooperation, it has been studied intensely about intraoral appliances and their mechanics for molar distalization. Among these appliances point-out the magnets $^{6}$, Jones jig ${ }^{7}$, superelastic coil springs ${ }^{8}$, Herbst ${ }^{9}$, distal jet ${ }^{10}$, pendulum, and Pendex ${ }^{11-14}$.

The pendulum initially described by Hilgers ${ }^{11,12}$ consisted of an intraoral appliance for maxillary molar distalization that did not provide transversal molar control while in movement, thus leading this dental element to cross. In order to avoid this undesirable movement, Hilgers ${ }^{13}$ added an expansion screw to it, thus originating Pendex. Some advantages of Pendex using include shorter treatment time, constant load on molars and it does not depend on patient cooperation during treatment ${ }^{15-17}$. For this reason, it is widely recommended by orthodontists. However, when compared to extraoral forces, the mechanics performed by Pendex may present some undesirable effects, such as: molar inclination, premolar mesialization and incisor anterior inclination ${ }^{18-20}$. These factors should be taken into consideration when planning orthodontic treatments ${ }^{5}$.

Considering that the maxillary molar distalization has an importance function on the treatment of Class II malocclusion and that there is limited number of prospective studies using the Pendex appliance, the objective of this study was to evaluate dental alterations in the maxilla and any possible vertical alterations result from the utilization of Pendex as the orthodontic treatment of choice for upper molar distalization.

\section{MATERIAL AND METHOD}

A convenience sample of ten patients of both genders (male: 4 and female: 6) and mean age of 15.3 years (range: 9.3 to 28.8 years old) with a need of orthodontics treatment was selected for participation in this study at Paulista University Dental School FOUNIP. The sample inclusion criteria were based on the anteroposterior first molar relationship in Angle Class II, regardless of other dentoalveolar or skeletal characteristics. The mean time of the orthodontic treatment time was 2 years.

Each subject gave written informed consent before entering the cohort, which was approved by the local ethical committee of the Paulista University-FOUNIP $\left(n^{\circ}\right.$ 106/09 CEP/ICS/UNIP).

Two lateral cephalometric radiographs were obtained for each patient, one at the beginning (T1) and the other after the distalization of the maxillary first molars (T2). The cephalograms were traced and measured by a calibrated operator and the data at $\mathrm{T} 2$ and $\mathrm{T} 1$ were compared between then for each patient.

All patients were treated with Pendex appliance similar to that described by Hilgers $(1998)^{13}$. The appliances were made by the same technician and consisted of an acrylic Nance button with an expansion screw, distalization coil springs (0.032" TMA wire), which were inserted into the lingual sheaths on the bands attached to the maxillary first molars, with occlusal supports adapted to the mesial marginal crest of the first premolar or deciduous molar, and distal from second premolar or deciduous molar (steel thread $0.08 \mathrm{~mm}$ ) (Figure 1).

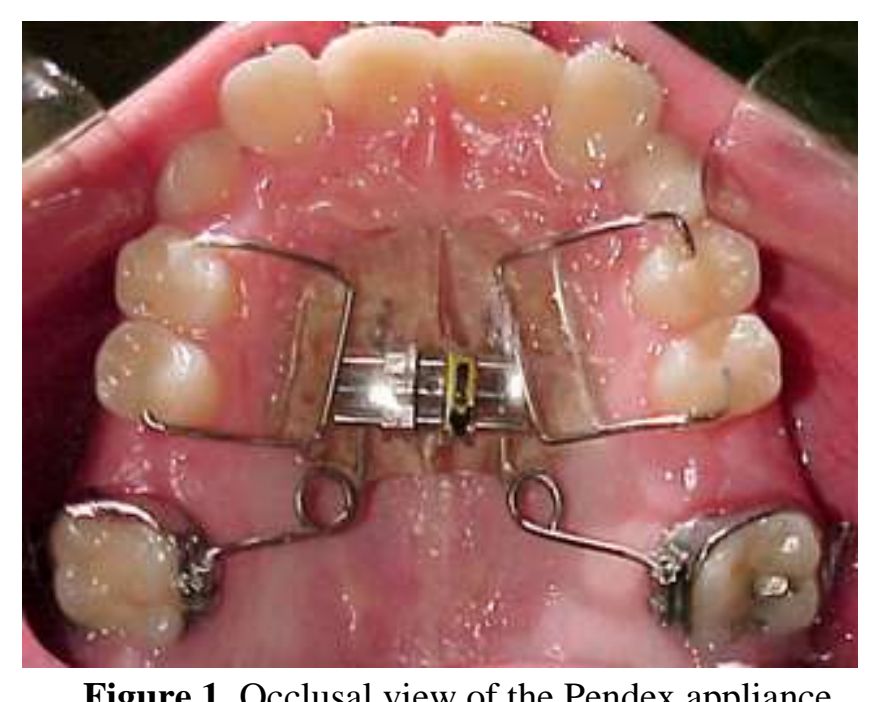

Figure 1. Occlusal view of the Pendex appliance positioned on the maxillary arch

Distalization springs were bent parallel to palatal midline with 230 to $250 \mathrm{~g}$ of force, measured with a dynamometer ${ }^{12}$. An uprighting bend was incorporated into the molar distalization spring to control excessive tipping of the maxillary molars ${ }^{22}$. Depending on the molar movement required, activation was repeated intraorally during the treatment, to attain overcorrection of Class I relationship. Expansion screw was activated with an $1 / 4$ turn $(0.25 \mathrm{~mm})$ every seven, fifteen or twentyone days, according to the individual needs of each treatment. The average time to achieve correction of Class II molar relationship was $5.9 \pm 6$ months. After distalization of first molars, occlusion supports of second premolars were removed to allow the distal movement of these teeth through the action of the transseptal fibers. Subsequently, the appliance was kept for 6 additional weeks to contain distalization.

All lateral radiographs used in the study were obtained from the same X-Ray appliance and with the same standardization for all patients. The cephalograms were traced on acetate paper by the one calibrated investigator (F.L.G.R.S) and verified by another (R.B.). 
The cephalometric measurements used to evaluate molars, premolars, maxillary incisor teeth and vertical alterations (cephalometric variables according to Ricketts analysis ${ }^{23}$ ) are described in Table 1 and presented graphically by the Figures 2 and 3 .

Table 1. Cephalometric variables measured

\begin{tabular}{|c|c|}
\hline Measurements & Description \\
\hline A6-PTV & $\begin{array}{l}\text { Linear distance between the most distal point of } \\
\text { first maxillary molar crown (A6) and the pterygoid } \\
\text { vertical plane (PTV) }\end{array}$ \\
\hline A4-PTV & $\begin{array}{l}\text { Linear distance between the most distal point of } \\
\text { the first maxillary premolar crown and PTV }\end{array}$ \\
\hline A1-PTV & $\begin{array}{l}\text { Linear distance between the tip of maxillary central } \\
\text { incisor perpendicular to the PTV }\end{array}$ \\
\hline A6.PP & $\begin{array}{l}\text { Angle formed by the intersection of the long axis of } \\
\text { the maxillary first molar, tangent to its distal face, } \\
\text { and the palatal plane (ANS-PNS) }\end{array}$ \\
\hline A4.PP & $\begin{array}{l}\text { Angle formed by the intersection of the long axis of } \\
\text { the maxillary first premolar tangent to its distal } \\
\text { face, and the palatal plane (PP) }\end{array}$ \\
\hline A1.PP & $\begin{array}{l}\text { Angle formed by the intersection of the long axis of } \\
\text { the maxillary central incisor and the palatal plane } \\
\text { (PP) }\end{array}$ \\
\hline A1.B1 & $\begin{array}{l}\text { Angle formed by the intersection of the long axis of } \\
\text { the maxillary central incisor and the long axis of } \\
\text { mandibule central incisor (B1) }\end{array}$ \\
\hline LFH & $\begin{array}{l}\text { Angle formed by Xi lines (center of mandibular } \\
\text { branch) - ANS (anterior nasal spine) and Xi-PM } \\
\text { (mentonian protuberance) }\end{array}$ \\
\hline FA & $\begin{array}{l}\text { Posterior angle formed between skull base plan } \\
\text { (Ba-Na) and facial axis (Pt-Gn) }\end{array}$ \\
\hline TFH & $\begin{array}{l}\text { Angle formed between skull base plans and Xi-PM } \\
\text { extension }\end{array}$ \\
\hline
\end{tabular}

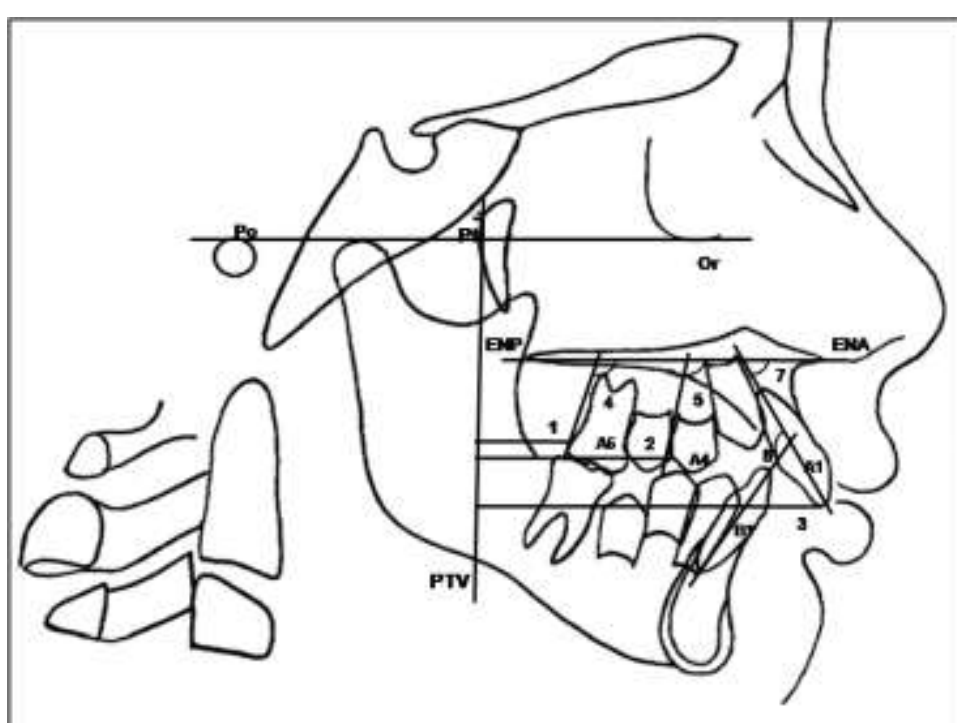

Figure 2. Dental variables: 1. A6-PTV, 2. A4-PTV, 3. A1-PTV, 4. A6.PP, 5. A4.PP, 6. A1.PP, 7. A1.B1

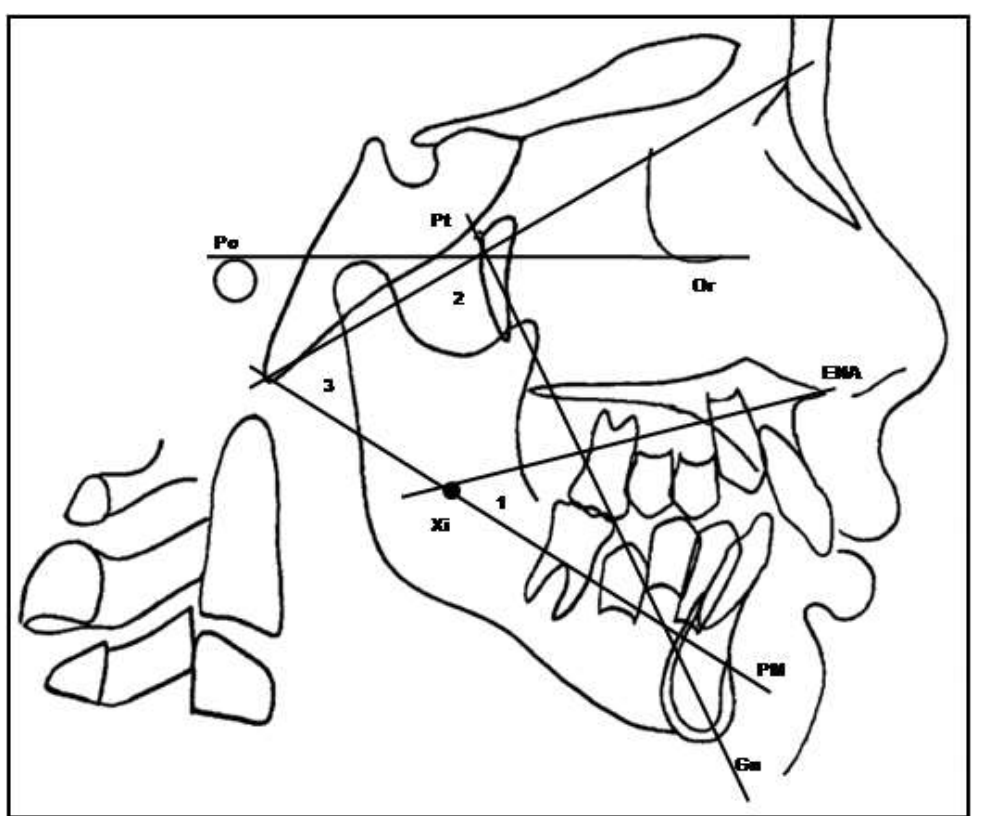

Figure 3. Vertical Variables: 1. AFI, 2. EF, 3. AFT
Descriptive statistics (mean and standard deviation) were calculated for each cephalometric variable at $\mathrm{T} 1$ and $\mathrm{T} 2$. The data $\left({ }^{0}\right)$ obtained were also analyzed by " $\mathrm{t}$ " test for paired samples at $5 \%$ level of significance.

\section{RESULTS}

The means and standard deviations for dentoalveolar and vertical alterations in $\mathrm{T} 1$ and $\mathrm{T} 2$ are presented in Table 2. The results demonstrated that according to the dentoalveolar changes, there was a statistically significant difference between the distances $(p=0.041)$ and inclinations $(p=0.004)$ of molars after the treatment (T2-T1). These findings confirm the distalization and distal tipping of the molars. However, when the variables related to maxillary incisors were evaluated, there was no statistically significant difference between T2 and T1 for distance (A1-PTV), tipping (A1.PP) and interincisal angle (A1.B1), but a little reduction for those variables was observed. Moreover, it can be observed that the position and tipping of maxillary premolar also did not show a statistically significant alteration after molar distalization ( $\mathrm{p}=0.379$ and $\mathrm{p}=0.124$, respectively); however, the difference between $\mathrm{T} 2$ and $\mathrm{T} 1$ of $1.2 \mathrm{~mm}$ (A4-PTV) and $3.6^{\circ}$ (A4.PP) suggests minimal loss of anchorage.

According to the vertical alterations, it was observed that total facial height $(\mathrm{p}=0.266)$ and facial axis angle $(p=0.213)$ remained practically constant difference after the distalization. However, lower facial height presented a statistically significant increase in T2 $(\mathrm{p}=0.031)$.

Table 2. Comparison of mean values of angular and linear cephalometric measures before (T1) and after (T2) molar distalization (" $t$ " test)

\begin{tabular}{ccccc}
\hline Variable & T1 & T2 & T2-T1 & $\begin{array}{c}\text { p- } \\
\text { value }\end{array}$ \\
\hline A4-PTV & $38.4 \pm 5.5$ & $39.65 \pm 2.8$ & $1.2 \pm 4.1$ & 0.379 \\
A4.PP & $99.5 \pm 6.5$ & $95.9 \pm 7.7$ & $-3.6 \pm 6.7$ & 0.124 \\
A6-PTV & $19.4 \pm 7.4$ & $14.5 \pm 4.5$ & $-4.9 \pm 6.5$ & $\mathbf{0 . 0 4 1 *}$ \\
A6.PP & $112.1 \pm 10.7$ & $121.5 \pm 8.7$ & $9.4 \pm 7.7$ & $\mathbf{0 . 0 0 4}$ \\
A1-PTV & $62.3 \pm 9.8$ & $60.9 \pm 4.7$ & $-1.4 \pm 7.3$ & 0.561 \\
A1.PP & $64.0 \pm 10.0$ & $63.9 \pm 9.1$ & $-0.1 \pm 8.9$ & 0.972 \\
A1.B1 & $117.8 \pm 9.6$ & $112.9 \pm 10.9$ & $-4.9 \pm 13.7$ & 0.286 \\
TFH & $57.3 \pm 3.4$ & $58.3 \pm 4.9$ & $1.0 \pm 2.7$ & 0.266 \\
LFH & $46.4 \pm 4.1$ & $48.1 \pm 5.0$ & $1.7 \pm 2.1$ & $\mathbf{0 . 0 3 1 *}$ \\
FA & $88.0 \pm 4.7$ & $87.0 \pm 5.0$ & $-1.0 \pm 2.4$ & 0.213 \\
\hline
\end{tabular}

*Statistically significant $(\mathrm{p}<0.05)$

\section{DISCUSSION}

The results found in this study indicate that Pendex have a predominantly dental action, without significant alterations on the vertical dimension. In this way, the comparison of lateral radiographs taken before and after the Pendex appliance showed a $4.9 \mathrm{~mm}$ molar distalization, that contributed substantially for the Class 
II correction. Similar distalization values were found in literature ${ }^{4,18,24,25}$

One of the main disadvantages of the Pendex appliance is undoubtedly the maxillary molars distal inclination. This study observed a $9.4^{\circ}$ inclination after the molar distalization. Similar $\left(8.36^{\mathrm{ol}}\right)$ and even greater values $\left(15.7^{\mathrm{o16}}\right)$ than those found in this research are reported in the literature. The mechanical explanation for this inclination lies in the localization of the load application point in relation to the center of molar resistance and in the impossibility of making the force action line go through the resistance center of the dental element being addressed ${ }^{21,26}$. In many times the eruption conditions of second maxillary molars influence significantly the distalization of first molars, because the unerupted germ of the second molar works like a fulcrum for the rotation of the first molar during its distalization, leading to an undesired distal tipping ${ }^{26}$. The implications of such inclination lie especially on compromised stability after treatment, because in some cases the relapse of distalization is as much as $90 \%{ }^{23}$. However, this distal inclination does not affect the final results, but limits the amount of distalization during orthodontic planning and also requires that care should be taken during distalization, like using an uprighting bend, overcorrection (practically Class III molar relationship) and stabilization of the distalized molar (6 to 10 weeks), after the removal of the distalizing appliance $^{4,21}$

According to Hilgers ${ }^{12}, 20 \%$ of the space obtained with distalization results from the loss of anchorage, which means that the anchorage used in the appliance, an acrylic support (Nance button) touching the palatine mucosa, did not manage to neutralize the reaction of the distalizing appliance ${ }^{14}$. Although there were no statistically significant differences, the results found in this study showed that the premolar presented a slight mesialization $(1.2 \mathrm{~mm})$ and inclination $\left(3.6^{\circ}\right)$, demonstrating a slight loss of anchorage. Other studies corroborate with these findings, with values of $1.8 \mathrm{~mm}$ and $1.5^{\circ 24}, 1.88 \mathrm{~mm}$ and $3.46^{\circ 4}, 2.23 \mathrm{~mm}$ and $2.37^{\circ 7}$. On the other hand, some studies have demonstrated large movements of premolars, with $3.6 \mathrm{~mm}$ mesialization and $6.5^{\circ}$ inclination $^{25}$. Probably, these differences among the studies are related to the different cephalometric variables used in each research.

According to central incisor, it was not found any significant changes. There was only a $1.4 \mathrm{~mm}$ increase in the distance to PTV, the inclination in relation to the palatal plane practically did not change $\left(0.1^{\circ}\right.$ reduction $)$ and the interincisal angle reduced about $5^{\circ}$. On the other hand, different results were found by other studies that reported mesialization and anterior inclination of the incisor, besides an extrusion of this dental element ${ }^{15,18,20}$. However, Byloff and Darendeliler ${ }^{21,22}$ concluded in their studies that the loss of anchorage in the region of incisors with the use of the pendulum is minimal and does not lead to any significant problems.

Furthermore, the results showed no statistically significant alterations on the total facial height or facial axis, corroborating with some studies that reported Pendex appliance has a predominantly dental-alveolar action ${ }^{9,24,25}$. Lower facial height, in contrast, presented a statistically significant increase between $\mathrm{T} 2$ and $\mathrm{T} 1$. The increase in the lower facial height reported by Ghosh and Nanda $^{18}$ was even greater, as much as $2.79 \mathrm{~mm}$ and similar to the those found by Chaques-Asensi and $\mathrm{Kalra}^{20}$ of $2.8 \mathrm{~mm}$ and by Bussick and McNamara ${ }^{24}$, who found $2.7 \mathrm{~mm}$. This values probably means that there was an increase in the height of the mandibular ramus, compensating these variables. However, we can't conclude that Pendex contributed to this ramus increase or whether it was just physiological growth, considering that most of the patients assessed were still growing. There is also the possibility of an alteration due to the extrusion of the distalized molar, which has been proven by many studies ${ }^{18,20,24}$.

Molar distal movement without use of the traditional extraoral force has become constant in orthodontics after the development of intraoral distalizers $^{28,29}$. In despite of these devices present advantages like constant force, shorter treatment time and the fact that they do not dependent on the compliance of patients; on the other hand, it is undeniable that these appliances present some mechanical disadvantages: anchorage loss, represented by the movement of anterior teeth contrary to the movement of the molar, and tipping of distalized molars. Thus, clinicians should have the necessary coherence during the orthodontic planning to obtain from distalizers results compatible with good orthodontic results. In this way, it is necessary to have a judgement planning to obtain distalizations with compatible magnitude to the outcome (up to half Class II), careful follow up of the effects induced by mechanics during the distalization and the use of wider anchorages, for example, unilateral distalizations, where the entire maxillary dental arch can be used as anchorage $e^{4,5,27}$.

Moreover, the results of this study should be considered with caution since they cannot be generalized because of the sample size of convenience sample used $^{28}$. However, similar results to this study have been found in the literature ${ }^{4,15,16,19}$. So, the low sample size could not be considerate as a great bias of this research. Thus, future studies should be developed with a greater number of patients to allow that the results can be extrapolated with more reliability.

\section{CONCLUSION}

Based on the results, it is possible to conclude that orthodontic treatment with Pendex is an effective alternative for maxillary molar distalization and thus the 
correction of Class II malocclusions, without the necessity of patient cooperation, once that the effects of the appliance are limited to the dentoalveolar structures.

As in every orthodontic mechanics, there may be adverse reactions. In this manner, care should be taken to minimize inclination and mesialization of the anterior dental segment.

\section{REFERENCES}

1. Moyers RE, Riolo ML, Guire KE, Wainright RL, Bookstein FL. Differential diagnosis of Class II malocclusions. Part 1. Facial types associated with Class II malocclusions. Am J Ortthod Dentofacial Orthop. 1980; 78(5):477-94.

2. Celtin NM, Tem-Hoeve A. Nonextraction treatment. J Clin Orthod. 1983; 17(6):396-413.

3. Brickman CD, Sinha PK, Nanda RS. Evaluation of the Jones jig appliance for distal molar movement. Am J Orthod Dentofacial Orthop. 2000; 118(5):52634.

4. Taner TU, Yukay F, Pehlivanoglu M, Çakiner B. A comparative analysis of maxillary tooth movement produced by cervical headgear and pendex appliance. Angle Orthod. 2003; 73(6):686-9.

5. Silva Filho OG, Santos ECA, Silva APJL, Bertoz APM. Distalização dos molares superiores com aparelho Pendex unilateral: estudo piloto com radiografia panorâmica Rev Dent Press Ortodon Ortopedi Facial. 2007; 12(1):56-66.

6. Bondemark L, Kurol J. Distalization of maxillary first and second molars simultaneously with repelling magnets. Eur J Orthod. 1992; 14(4):264-72.

7. Patel MP, Janson G, Henriques JFC, Almeida RR, Freitas MR, Pinzan A, Freitas KMS. Comparative distalization effects of Jones jig and pendulum appliances. Am J Ortthod Dentofacial Orthop. 2009; 135(3):336-42.

8. Erverdi N, Koyuturk O, Kucukkeles N. Nickeltitanium coil springs and repelling magnets: a comparison of two different intra-oral molar distalization techniques. Br J Orthod. 1997; 24(1):4753.

9. Burkhardt DR, McNamara Jr JA, Baccetti T. Maxillary molar distalization or mandibular enhancement: a cephalometric comparison of comprehensive orthodontic treatment including the pendulum and the Herbst appliances. Am J Orthod Dentofacial Orthop. 2003; 123(2):108-16.

10. Carano A, Tests M. Distal jet for upper molar distalization. J Clin Orthod. 1996, 30(7):374-80.

11. Hilgers JJ. A palatal expansion appliance for noncompliance therapy. J Clin Orthod. 1991;25(8):4917.

12. Hilgers JJ. The pendulum appliance for Class II noncompliance therapy. J Clin Orthod. 1992; 26(11):706-14.
13. Hilgers JJ. Hyperefficient orthodontic treatment using tandem mechanics. Semin Orthod. 1998; 4(1):17-25.

14. Santos ECA, Silva Filho OG, Reis PMP, Bertoz FA. Distalização dos molares superiores com aparelho Pendex: estudo em modelos de gesso. Rev Dent Press Ortodon Ortope Facial. 2006; 11(3):71-80.

15. Kinzinger G, Fuhrmann R, Gross U, Diedrich P. Modified pendulum appliance including distal screw and uprighting activation for non-compliance therapy of Class II malocclusion in children and adolescents. J Orofac Orthop. 2000; 61(3):175-90.

16. Joseph AA, Butchart CJ. An evaluation of the pendulum "distalizing" appliance. Semin Orthod. 2000; 6(2):129-35.

17. Toroglu MS, Uzel I, Çam OY, Hancioglu ZB. Cephalometric evaluation of the effects of pendulum appliance on various vertical growth patterns and of the changes during short-term stabilization. Clin Orthod Res. 2001; 4(1):15-27.

18. Ghosh J, Nanda RS. Evaluation of an intraoral maxillary molar distalization technique. Am J Orthod Dentofacial Orthop. 1996; 110(6):639-46.

19. Scuzzo G, Pisani F, Takemoto K. Maxilary molar distalization with a modified pendulum appliance. J Cin Orthod. 1999; 33(11):645-50.

20. Chaques-Asensi J, Kalra V. Effects of the pendulum appliance on the dentofacial complex. J Clin Orthod. 2007; 35(4):254-7.

21. Byloff FK, Darendeliler MA. Distal molar movement using the pendulum appliance. Part 1: clinical and radiological evaluation. Angle Orthod. 1997; 67(4):249-60.

22. Byloff FK, Darendeliler MA, Clar E, Darendeliler A. Distal molar movement using the pendulum appliance. Part 2: the effects of maxillary molar root uprighting bends. Angle Orthod. 1997; 67(4):261-70.

23. Ricketts, RM. Provocations and perceptions in craniofacial orthopedics. Glendora: RMO, p.9961004; 1989.

24. Bussick TJ, McNamara JA Jr. Dentoalveolar and skeletal changes associated with the pendulum appliance. Am J Orthod Dentofacial Orthop. 2000; 117(3):333-43.

25. Angelieri F, Almeida RR, Almeida MR, Fuziy A. Dentoalveolar and skeletal changes associated with the pendulum appliance followed by fixed orthodontic treatment. Am J Orthod Dentofacial Orthop. 2006; 129(4):520-7.

26. Kinzinger GSM, Fritz UB, Sander FG, Diedrich PR. Efficiency of a pendulum appliance for molar distalization related to second and third molar eruption stage. Am J Orthod Dentofacial Orthop. 2004; 125(1):8-23.

27. Schutze SF, Gedrange T, Zellmann MR, Harzer W. Effects of unilateral molar distalization with a 
modified pendulum appliance. Am J Orthod Dentofacial Orthop. 2007; 131(5):600-8.

28. Fontana M1, Cozzani M, Caprioglio A. Noncompliance maxillary molar distalizing appliances: an overview of the last decade. Prog Orthod. 2012; 13(2):173-84.

29. Patil RU, Prakash A, Agarwal A. Pendulum Therapy of Molar Distalization in Mixed Dentition. Int J Clin Pediatr Dent. 2016; 9(1):67-73.

\section{CONFLICTS OF INTERESTS}

The authors declare no conflicts of interests.

\section{CORRESPONDING AUTHOR}

\section{Renato Bigliazzi}

bigliazzi@foa.unesp.br

Received 15/05/2016 Accepted 27/06/2016 